\title{
Insulin action on skeletal muscle protein metabolism during catabolic states
}

\author{
Jean Grizard*, Dominique Dardevet, Michèle Balage, Daniel Larbaud, \\ Sandrine Sinaud, Isabelle Savary, Katarzyna Grzelkowska, \\ Cécile Rochon, Igor Tauveron, Christiane Obled
}

Unité d'étude du métabolisme azoté, Inra centre de Clermont-Ferrand/Theix, centre de recherche en nutrition humaine d'Auvergne, 63122 Saint-Genès-Champanelle, France

(Received 13 August 1998; accepted 2 December 1998)

\begin{abstract}
Insulin plays a major role in the regulation of skeletal muscle protein turnover but its mechanism of action is not fully understood, especially in vivo during catabolic states. These aspects are presently reviewed. Insulin inhibits the ATP-ubiquitin proteasome proteolytic pathway which is presumably the predominant pathway involved in the breakdown of muscle protein. Evidence of the ability of insulin to stimulate muscle protein synthesis in vivo was also presented. Many catabolic states in rats, e.g. streptozotocin diabetes, glucocorticoid excess or sepsis-induced cytokines, resulted in a decrease in insulin action on protein synthesis or degradation. The effect of catabolic factors would therefore be facilitated. In contrast, the antiproteolytic action of insulin was improved during hyperthyroidism in man and early lactation in goats. Excessive muscle protein breakdown should therefore be prevented. In other words, the anabolic hormone insulin partly controlled the 'catabolic drive'. Advances in the understanding of insulin signalling pathways and targets should provide information on the interactions between insulin action, muscle protein turnover and catabolic factors. (C) Inra/ Elsevier, Paris.
\end{abstract}

insulin / skeletal muscle / protein synthesis / protein breakdown / catabolic states

Résumé - Action de l'insuline sur le métabolisme protéique musculaire au cours des états cataboliques. L'insuline joue un rôle majeur dans la régulation du métabolisme protéique musculaire mais son mécanisme d'action n'est pas complétement connu, notamment in vivo durant les états cataboliques. Nous avons rapporté dans cette revue les données récentes qui démontrent que l'insuline inhibe la protéolyse ATP-ubiquitine-protéasome dépendante dans le muscle. Cette voie protéolytique joue un rôle fondamental dans la dégradation des protéines musculaires. Nous avons aussi apporté la preuve que l'insuline est capable de stimuler la synthèse des protéines musculaires in vivo. Dans de nombreux états cataboliques comme le diabète induit par la streptozotocine, l'hyper-

* Correspondence and reprints 
glucocorticoïdémie et le sepsis chez le rat, il y a une réduction de l'effet de l'insuline sur la synthèse ou la dégradation des protéines musculaires. Cela pourrait faciliter l'action des facteurs cataboliques. Au contraire, pour l'hyperthyroïdie chez l'homme et le début de la lactation chez les ruminants, l'action antiprotéolytique de l'insuline est renforcée. Cela pourrait éviter une mobilisation excessive de protéines musculaires. L'induction du catabolisme serait donc toujours contrôlée par une hormone à action anabolique, l'insuline. Le développement des connaissances sur les voies de signalisation intracellulaires de l'insuline et ses cibles, devrait considérablement accroître la compréhension des interactions entre l'insuline, le métabolisme protéique musculaire et les facteurs cataboliques. (C) Inra/Elsevier, Paris.

\section{insuline / muscle squelettique / synthèse protéique / protéolyse / état catabolique}

\section{INTRODUCTION}

There is considerable evidence that insulin plays a major role in the regulation of muscle protein metabolism, but its mechanism of action is not fully understood [ 37 , $51,56,67]$. The purpose of the present review is: i) to analyse the action of the hormone on muscle protein synthesis and degradation in vivo; ii) to determine whether changes in insulin action could modulate muscle wasting during catabolic states (e.g elderly and lactation); and iii) to understand the mechanism of changes in insulin action at the level of signalling and targets.

\section{INSULIN ACTION ON MUSCLE PROTEIN TURNOVER}

\subsection{Protein synthesis}

As summarised by Kimball et al. [47] synthesis of new protein in eukaryotic cells is achieved via a complex series of discrete reactions that occur in the nucleus, cytosol and various subcellular locations. In the nucleus, transcription of specific genes by three classes of RNA polymerases results in the production of mRNA, tRNA, 5S RNA and $45 \mathrm{~S}$ preribosomal RNA. The RNA products are processed and, in the case of mRNA and tRNA, are transported to the cytoplasm. The $45 \mathrm{~S}$ preribosomal RNA is processed to yield the mature $18 \mathrm{~S}, 5.8 \mathrm{~S}$ and
28S RNA constituents of the ribosome. These three products along with the 5S RNA and $\sim 5$ ribosomal proteins move to the nucleolus where they are assembled into the $40 \mathrm{~S}$ and $60 \mathrm{~S}$ preribosomal particles which are then transported to the cytoplasm. In the cytoplasm, the ribosomal particles bind to mRNA to form polysomes, which can exist free or bound to the endoplasmic reticulum, cytokeleton, and perhaps other subcellular structures. Protein synthesis in the cytoplasm begins with the aminoacylation of tRNA and ends with the release of a completed peptide chain from a polysome. Translation of mRNA into protein by ribosomes is usually divided into three phases: a) initiation, in which the initiator methionyltRNA is bound to mRNA, which in turn binds first to a $40 \mathrm{~S}$ ribosomal subunit and subsequently to a $60 \mathrm{~S}$ subunit, thus forming a translationally competent ribosome [62]; b) elongation, during which tRNA bound amino acids are incorporated into a growing peptide chain in the order specified by the mRNA to which the ribosome is bound; and c) termination, the phase when the completed peptide chain is released from the ribosome. Each of these steps requires the intervention of protein factors known collectively as eukaryotic initiation factors (eIF), elongation factors (eEF) and releasing factors [66].

Experimental studies at the cellular level or in incubated muscles from young adult organisms have generally demonstrated that 
insulin stimulates protein synthesis [17]. Surprisingly, insulin fails to stimulate protein synthesis in vivo $[23,54,78]$. Because insulin administration results in a decline in plasma amino acid concentrations, more recent studies have examined insulin-related responses when amino acid availability was maintained by exogenous amino acid infusion or in experiments with local administration of small doses of the hormone. However, these experiments did not reveal any increase in whole body amino acid disposal $[13,27$, $33,41,77,79$ ], muscle amino acid uptake $[29,32,41,52,57]$ or protein synthesis rates [76].

Some authors recorded a significant effect of insulin in adult humans but we feel that their effect was artefactual. For example, the strong stimulation of muscle protein synthesis recently observed in the forearm [42] could be related to an IGF1 receptor signalling owing to the extreme hyperinsulinemia. The study by Bennett et al. [8] compared the effect of amino acid infusion and of insulin infusion combined with amino acids on protein synthesis. The latter group was observed to have a greater rate of protein synthesis than the former. However, the assay was not matched for amino acid concentrations. Indeed, the group receiving insulin with amino acids included higher amino acid infusion rates and substantially higher plasma concentrations of amino acids. The difference between the two groups could therefore be related to amino acids. The publication of Biolo et al. [9] is more questionable. It included both tracer-balance measurements and tissue biopsies. Good internal agreement was obtained between results seen with the arterio-venous difference method and the biopsy technique, both showing an enhancement of muscle protein synthesis by physiologic hyperinsulinemia. However a specific amino acid kinetics model was used which did not reveal any insulin-inhibited proteolysis. The Biolo paper stands alone in reporting such findings.
In fact, the only published evidence of a significant increase in muscle protein synthesis under physiological hyperinsulinemia was reported in growing rats after a short period of fasting $[30,31]$. These young animals showed a very high insulin sensitivity, especially when branched chain amino acids were present. Accordingly, looking at the relationship between insulin and muscle protein synthesis, Millward and Rivers [56] reported that parallel changes in the two parameters were only observable in the low insulin range because additional provision of insulin to fed rats failed to further stimulate muscle protein synthesis [6]. The maximum insulin effect may be already obtained at postprandial insulin levels. All studies indicated that the stimulatory effect of insulin on muscle protein synthesis observed in young rats was blunted in adults $[7,53,58]$ except following resistance exercise [28]. The same concepts were drawn from recent experiments in young pigs [21].

In order to have a better understanding of the ability of insulin to regulate skeletal muscle protein synthesis in vivo, we investigated the effect of a postprandial acute insulin deficiency after diazoxide injection on rat skeletal muscle protein synthesis [72]. Diazoxide administration lowered plasma insulin over $85 \%$ within $3 \mathrm{~h}$ after injection whereas other hormones (IGF-I, glucagon, corticosterone) involved in the regulation of muscle protein synthesis were not significantly altered compared to control animals. The fractional rate of muscle protein synthesis, measured in vivo, was significantly reduced in epitrochlearis $(-46 \%)$ gastrocnemius $(-41 \%)$ and soleus $(-35 \%)$ $(P<0.05)$. The protein synthesis reduction did not result from a reduced total RNA content but was associated with diminished translation efficiency. Analysis of ribosomal subunits revealed that the decreased translation efficiency resulted from an impairment in the initiation phase of protein synthesis.

One of the most regulated steps in translation initiation is the binding of mRNA to 
the 40S subunit [62] (figure 1). This step involves several initiation factors constituting elF4F which catalyse the association. The component of eIF4F that binds to the $m^{7}$ GTP cap at the 5' end of the mRNA is eIF4E. The subsequent binding of the eIF4E mRNA complex to another initiation factor, eIF4G, is a critical step in the formation of the $48 \mathrm{~S}$ preinitiation complex. Regulation of the binding of eIF4E to eIF4G involves protein, 4E-BP1 (also called PHASI). In vivo, eIF4E can bind to either 4E-BP1 or eIF4G but not simultaneously [40]. This finding, in combination with the

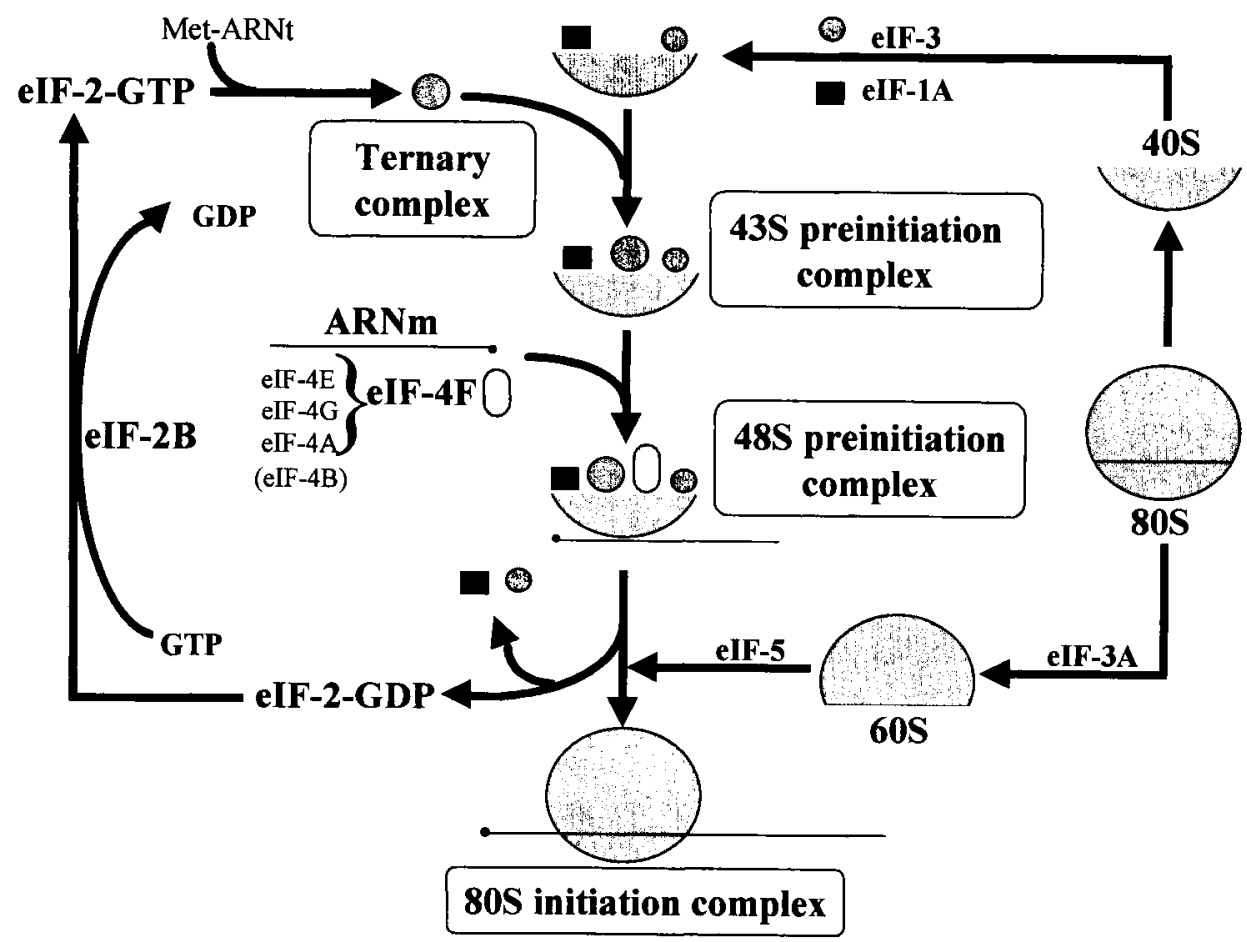

Figure 1. Mechanism of protein synthesis initiation. Stage 1, $80 \mathrm{~S}$ ribosomes dissociate, and $40 \mathrm{~S}$ subunits are captured for initiation by binding eIF1A and eIF3; the size of the latter causes the particle to sediment at 43S. Initiation tRNA (Met-tRNA ${ }_{f}$ ) binds, in the form of a ternary complex with eIF 2 and GTP, to give the $43 S$ preinitiation complex. Stage 2 , the $43 S$ preinitiation complex binds to mRNA at the 5 ' terminal $\mathrm{m}^{7} \mathrm{GTP}$ cap structure, and then migrates along the mRNA towards the AUG initiation codon. The initial binding involves the factors eIF4E, eIF4G and eIF4A, which assemble at the 5 '-end of mRNA, creating conditions that allow the melting of intramolecular secondary structures within the mRNA that would otherwise prevent the binding of the $43 \mathrm{~S}$ preinitiation complex. In the vast majority of cases the most 5' AUG codon is used for initiation. The term 48S preinitiation complex is frequently used, and refers to the $43 \mathrm{~S}$ globin-mRNA complex. Stage 3 , when the $43 \mathrm{~S}$ preinitiation complex stops at the initiation codon, the GTP molecule introduced as part of the eIF2 complex is hydrolysed to GDP, and this powers the ejection of the initiation factors bound to the $40 \mathrm{~S}$ ribosomal subunit. The initiation factor eIF5 is involved in this process. The release of these factors permits the association of a native $60 \mathrm{~S}$ ribosomal subunit, to reconstitute an $80 \mathrm{~S}$ ribosome at the initiation codon poised to commence the elongation stage of translation. The continuity of initiation events requires the recycling of initiation factor molecules. eIF2 is released as a binary complex with GDP and requires a guanine nucleotide exchange factor, eIF2B, to catalyse the regeneration of the eIF2. GTP complex required to recruit the next Met-tRNA, molecule (see [62] for more details). 
observation that the amino acid sequence of the eIF4E binding domain of the two proteins is homologous, suggests that eIF4G and 4E-BP1 compete for binding to eIF4E. Diazoxide-induced insulin deficiency was associated with a dramatic decrease in eIF4G bound to eIF4E and a 2.5-fold increase in the amount of the eIF4E-4E-BP1 complex [72]. In contrast, diazoxide did not change either the relative amount of eIF4E present in gastrocnemius nor its phosphorylation state. These results indicate that insulin is directly involved in the association of eIF-4E with either 4E-BP1 or eIF$4 \mathrm{G}$ to regulate the initiation of protein synthesis. Phosphorylation of $4 \mathrm{E}-\mathrm{BP} 1$ is presumably a key in insulin action $[48,49$, 89] (figure 2).

By using other animal models (e.g. streptozotocin diabetic rats), it has been shown that insulin may also control the initiation of protein synthesis by altering the phosphorylation of eIF-2B, which is a guanine nucleotide exchange factor required for recycling eIF2 by exchanging eIF-2-bound guanosine 5'-diphosphate (GDP) for GTP. The regulation of eIF-2B activity and protein synthesis seems to be closely linked [ 45 , 82]. Insulin has been shown to also act on other steps of translation (ribosomal proteins, elongation factors) and gene transcription [47].

\subsection{Protein degradation}

Skeletal muscles, like other mammalian tissues, contain several proteolytic systems. The best known proteolytic pathway is the lysosomal process. Muscles also contain two major cytosolic proteolytic pathways, a $\mathrm{Ca}^{2+}$-dependent [44] and an ATP-ubiquitin-dependent pathway [25]. The major lysosomal proteinases (cathepsins B, H, L and D) and the $\mathrm{Ca}^{2+}$-dependent proteinases $(\mu$-and $m$-calpains that differ in their affinities for $\mathrm{Ca}^{2+}$ ), do not contribute significantly to increased skeletal muscle proteolysis in many muscle wasting conditions, and do not play a major role in the degradation of myofibrillar proteins [55]. In contrast, the ATP-ubiquitin-dependent proteolytic pathway, which was previously believed to degrade abnormal and short-lived proteins

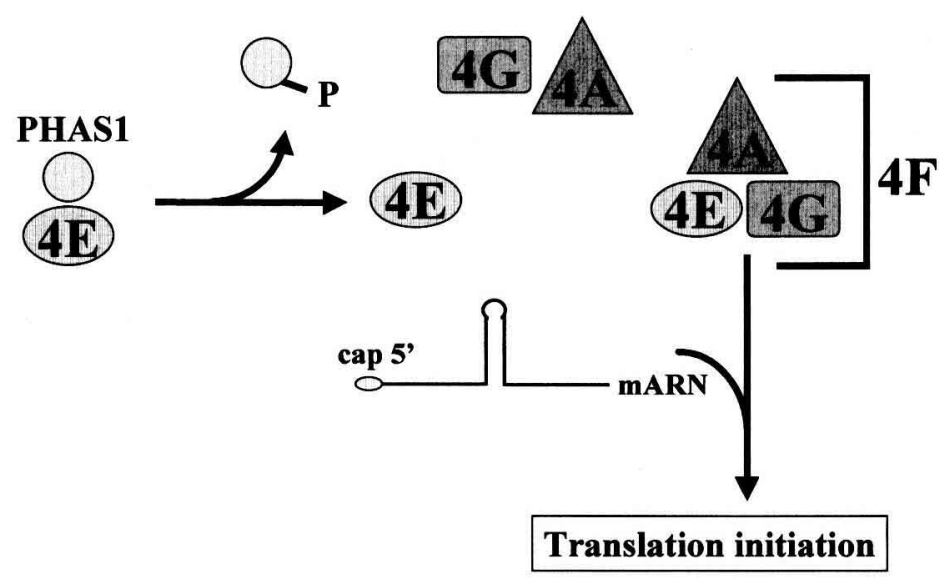

Figure 2. Possible insulin action on the initiation of protein synthesis. Insulin promotes the phosphorylation of 4E-BP1 (PHAS-1) and therefore the dissociation of eIF-4E (4E). The eIF-4E then binds to eIF-4G (4G) to give the complex eIF-4E/elF-4G/eIF-4A (4F). This complex allows initiation of protein synthesis. 
$[16,65]$, is presumably the critical system responsible for the breakdown of the longlived contractile components [81]. In this pathway, ubiquitin first covalently binds to protein substrates in a multistep process requiring ATP, and serves as a signal for degradation [16]. Ubiquitin-protein conjugates are then preferentially degraded by a very large $1500 \mathrm{kDa}(26 \mathrm{~S})$ proteolytic complex that also requires ATP for activation and substrate hydrolysis [36]. The $26 \mathrm{~S}$ complex consists of the $20 \mathrm{~S}$ proteasome core, a multicatalytic proteinase composed of 14 different subunits, plus regulatory components containing several proteins including APTases [1-3].

Insulin has a well-known antiproteolytic effect in muscle preparations [46]. The hormone downregulated mRNA levels for the $14 \mathrm{kDa}_{2}$ in cultured myoblasts, suggesting inhibition of the ubiquitin-proteasome pathway [86]. Although it is well documented that insulin inhibits in vivo protein breakdown at the whole body level, neither the tissues nor the proteolytic pathways on which insulin exerts its antiproteolytic effect are well characterized. The effects of insulin on mRNA levels for cathepsin D, m-calpain and ubiquitin were determined in vivo, in skeletal muscle, skin, liver and intestine [50]. A 6-h hyperinsulinemic, euglycemic and hyper aminoacidemic clamp was performed in goats, a species in which insulin markedly inhibited whole-body protein breakdown under similar conditions [79]. Hyperinsulinemia and hyper aminoacidemia only depressed ubiquitin mRNA levels in fast-twitch and mixed skeletal muscles without any concomitant reduction in mRNA levels for the $14 \mathrm{kDa} \mathrm{E}_{2}$ and $20 \mathrm{~S}$ proteasome subunits. The reduced ubiquitin mRNA levels in skeletal muscle may represent a possible mechanism explaining the antiproteolytic effect of insulin in vivo.

Other evidence for the antiproteolytic action of insulin in skeletal muscle in vivo was recently obtained in growing rats. Incubated muscles taken from diazoxide-treated animals (i.e. with an acute hypoinsulinemia during the postprandial state, see above) exhibited higher rates of proteolysis than their controls (S. Sinaud, M. Balage and J. Grizard, unpublished results). Conversely, muscles in vitro showed a lower rate of proteolysis when taken in postabsorptive animals under hyperinsulinemic-euglycemic clamp (D. Larbaud and D. Attaix, unpublished results). This decrease was abolished in the presence of specific proteasome inhibitors in the incubation medium. Moreover, studies on the expression of factors and cofactors involved in the proteolytic pathways correlated with results obtained in goats. The ATP-ubiquitin-proteasome dependent is, no doubt, a target for insulin in vivo. This does not preclude that insulin may have an inhibitory effect on muscle proteolysis by alternative mechanisms [24].

\subsection{Insulin signalling}

Binding of insulin to its receptors results in phosphorylation of specific intracellular proteins that are thought to act as transducers of the hormone signal $[4,15,59,87]$. Upon insulin binding and its autophosphorylation, the insulin receptor (IR) phosphorylates various endogenous substrates such as IRS-1 (insulin receptor substrate-1) and Shc (Src homology and collagen protein). IRS- 1 is considered as the major IR substrate in mammalian species. The tyrosine phosphorylation on specific motifs (YXXM, YMXM) allows IRS-1 to interact with several proteins through their SH2 domains such as PI 3'kinase, Grb2, SHPTP2. Grb2 is thought to be linked to the activation of Ras, which subsequently activates the mitogenactivated-protein (MAP) kinase pathway. Wortmannin and LY294002 (inhibitors of PI 3 'kinase) abolished the stimulation of protein synthesis by insulin in epitrochlearis muscle incubated in vitro [19]. LY294002 also totally reversed the antiproteolytic action of this hormone. Although $\mathrm{p} 70^{\mathrm{S} 6 \mathrm{~K}}$ activation by insulin may be mediated by PI 3'kinase in epitrochlearis muscle, the 
inhibition of the pathway including this kinase by rapamycin (blockage of the mammalian target of rapamycin mTOR) only diminished but did not abolish the stimulation of protein synthesis by the hormone. Rapamycin had no effect on proteolysis. These observations provide evidence that PI 3'kinase and $\mathrm{p} 70^{\mathrm{S} 6 \mathrm{~K}}$ play a role in the regulation of muscle protein turnover by insulin in epitrochlearis muscle (figure 3) and that some mTOR-independent elements are also involved in this regulation.

In contrast, the MAP-kinase pathway does not seem to be involved in the insulinregulated muscle protein turnover. Indeed insulin did not modify the phosphorylation status of both $\mathrm{p} 42^{\mathrm{mapk}}$ and $\mathrm{p} 44^{\mathrm{mapk}}$ isoforms

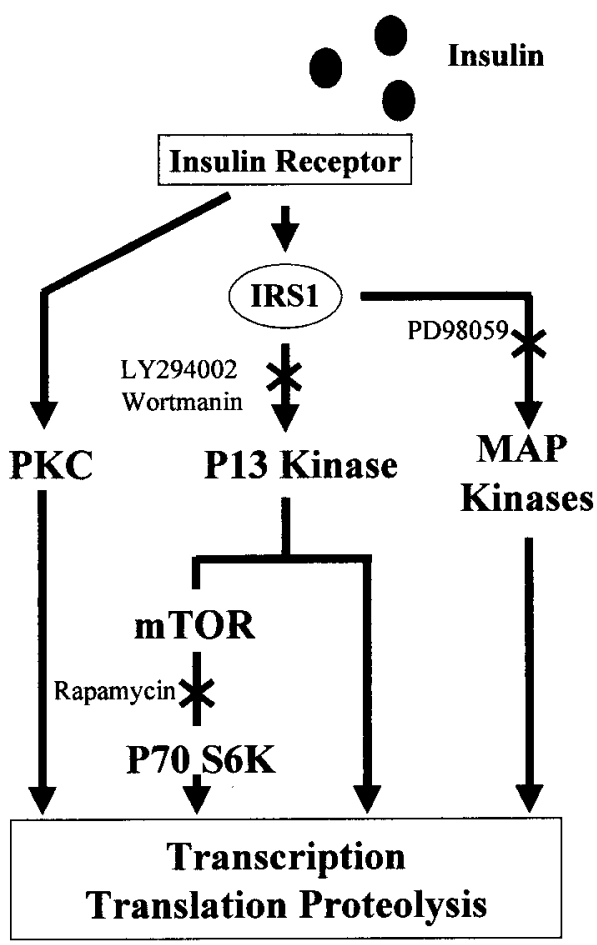

Figure 3. Possible insulin signalling pathways in the regulation of skeletal muscle protein turnover. Only major known pathways are indicated. Inhibitors (LY294002, wortmanin, rapamycin, PD98059) are useful for studying insulin signalling. nor their activities. An inhibition of this pathway (PD 98059) failed to change insulin actions on both protein synthesis and degradation. In our experiments, insulin stimulated the activity of $\mathrm{p} 90^{\mathrm{RSK}}$ independently of MAP-kinase. This is surprising since $\mathrm{p} 90^{\mathrm{RSK}}$ is more often considered as a downstream element of MAP-kinases.

Although considerable advances have been made in recent years in the area of signalling pathways and the regulation of protein turnover in skeletal muscle, it is clear that much remains to be investigated. The links between kinases and targets of insulin have to be established. For example insulin may stimulate phosphorylation of $4 \mathrm{E}-\mathrm{BP} 1$ through multiple signal transduction pathways, including the $\mathrm{p} 70^{\mathrm{S} 6 \mathrm{~K}}$ pathway. Insulin may also stimulate phosphorylation of eIF$2 \mathrm{~B}$ through the $\mathrm{p} 90^{\mathrm{RSK}} / \mathrm{GSK}-3$ pathway. The involvement of other pathways (protein kinases A, B and C; PKA, PKB and PKC, respectively) has yet to be determined [11, $47,48,62,66,80]$.

\section{EFFECT OF CATABOLIC FACTORS}

\subsection{Streptozotocin diabetes}

The diabetes-associated muscle atrophy is a consequence of both decreased protein synthesis and increased protein degradation. Several lines of evidence showed that muscle protein synthesis in diabetic rats is markedly reduced, especially in fast-twitch muscle, and that this effect is attributed to an impairment of peptide chain initiation [26, 61]. Elevated proteolysis has already been claimed in skeletal muscle of diabetic rats [5, 63]. It appeared that enhanced protein breakdown in skeletal muscle observed during the acute phase of diabetes results from an activation of the ATP-ubiquitin-dependent proteolytic system [5, 63].

Insulin resistance in 3-day-streptozotocin (STZ)-treated rats was manifested by the lack of antiproteolytic action of insulin as 
well as by a reduction of its stimulatory effect on protein synthesis in epitrochlearis muscle incubated in vitro $(-60 \%$ in comparison to control group) [39]. Until now, the mechanism underlying the insulin resistance was not completely understood. The STZ diabetes is accompanied by an increased insulin binding but alters insulin receptor tyrosine kinase in skeletal muscle [12]. After acute insulin stimulation in vivo, IRS-1 phosphorylation is several-fold higher and markedly prolonged, compared to the controls $[34,69]$.

We have investigated the diabetes-associated alterations in the insulin signalling cascade. LY 294002, a specific inhibitor of PI 3'kinase, markedly decreased the basal rate of protein synthesis and completely prevented insulin-mediated stimulation of this process both in control and diabetic rats. Thus, PI 3'kinase is required for insulinstimulated muscle protein synthesis in diabetic rats as in the controls. Rapamycin, an inhibitor of mTOR, had no effect on the basal rate of protein synthesis in either experimental group or control group. In control rats, the stimulatory action of insulin on muscle protein synthesis was diminished by $36 \%$ in the presence of rapamycin, whereas in diabetic muscles this reduction amounted to $68 \%$. In diabetic rats, the rapamycin-sensitive pathway makes a relatively greater contribution to the stimulatory effect of insulin on muscle protein synthesis than in the controls, presumably due to the preferential decrease in the rapamycin-insensitive component of protein synthesis. Both basal and insulin-stimulated $\mathrm{p} 70^{\mathrm{S} 6 \mathrm{~K}}$ activity, a signalling element lying downstream of mTOR, were not modified by STZ diabetes [39].

It is important to note that STZ diabetic rats show high levels of plasma glucagon, corticosterone and cytokines along with depressed IGF1. No direct relationship could therefore be established between the effects of diabetes and insulin deprivation per se.

\subsection{Glucocorticoid excess}

Muscle protein turnover was investigated in dexamethasone-treated rats (approximately $500 \mu \mathrm{g} / \mathrm{kg} /$ day in drinking water for 5-6 days) and their pair-fed controls both in vivo and in vitro. The glucocorticoid treatment of adult rats significantly decreased protein synthesis in glycolytic and oxidoglycolytic muscles in vivo. The effect was even greater in old rats $[70,71]$. Similar results were observed when protein synthesis was measured in epitrochlearis muscle incubated in the presence of insulin. In contrast, in the absence of insulin, in vitro protein synthesis only showed a significant decrease in old dexamethasone-treated rats but not in adults. This difference between results in the presence and in the absence of insulin was explained by: i) a lower responsiveness to insulin in glucocorticoidtreated rats rather than in controls; and ii) this insulin-resistant state after glucocorticoids was greater in old rather than adult rats $[20,38,71]$.

Regarding proteolysis in vitro in the absence of insulin, the glucocorticoid treatment only stimulated this pathway in adult but not in old rats. The target of glucocorticoids was the ATP-ubiquitin proteasome system [18]. An increase in proteolysis was visible in both groups in the presence of insulin (although of minor importance in old rats) because the glucocorticoid treatment always blunted the antiproteolytic action of insulin [20].

The effect of the dexamethasone treatment on muscle protein turnover was therefore both a reflexion of the action of glucocorticoids but also the consequence of an insulin-resistant state. The glucocorticoidinduced hyperinsulinemia could not overcome this insulin resistance [60]. The mechanism by which steroids alter insulin action on skeletal muscle remains unclear. Indeed, the first cellular events involved in the action of insulin (i.e. insulin receptor number) insulin receptor autophosphorylation and 
tyrosine phosphorylation of IRS- $1[10,35$, $68,69]$ are not modified by glucocorticoid treatment. Up to now, the only difference recorded in these conditions was the decrease in the association/activation of PI 3 'kinase with IRS-1 in response to insulin. We recently demonstrated that the glucocorticoid-associated insulin resistance is associated with a total blockage of $\mathrm{p} 70^{\mathrm{S} 6 \mathrm{~K}}$ stimulation by insulin without significant decrease in the amount of the kinase. However, the effect of rapamycin (inhibitor of several intracellular pathways including p $70^{\mathrm{S} 6 \mathrm{~K}}$ pathways) on muscle protein synthesis was not modified by dexamethasone in rat muscles. This suggested that 'rapamycin-sensitive pathways' associated to the insulin stimulation of protein synthesis were not altered by glucocorticoids and thus are not responsible for the observed insulin resistance. Glucocorticoids did not alter the effect of insulin on $\mathrm{p} 90^{\mathrm{RSK}}$ activity or MAPkinase pathways (although the latter is not involved in the insulin-regulated protein turnover in intact epitrochlearis muscle) [19].

\subsection{Cytokines}

We investigated the ability of insulin to modify protein metabolism during incubation of epitrochlearis 2 days following injection of live $E$. coli $[85]$. At that time, skeletal muscle exhibited an exacerbated negative protein balance resulting from both an inhibition in protein synthesis $(25 \%)$ and an enhanced proteolysis ( $90 \%$ ) compared with pair-fed controls. Insulin or IGF1 stimulated to the same extent both protein synthesis in muscles from septic and control rats in vitro. In contrast, the ability of insulin to limit protein degradation was severely hindered. This alteration in insulin action was prevented by treatment of animals with pentoxifylline. Such a treatment markedly decreased the sepsis-induced secretion of TNF $\alpha$, IL1 and IL6.

It was therefore suggested that cytokines could alter the antiproteolytic action of insulin on skeletal muscle. This is not surprising since IRS-1 has been shown to be involved in the signalling pathways of cytokines. For example, TNF $\alpha$ induces serine phosphorylation of IRS-1. Consequently, IRS-1 can now inhibit the insulin receptor tyrosine kinase activity $[64,88]$. Other interactions between insulin and cytokine transduction pathways have also been proposed $[74,88]$. The cytokine-induced insulin resistance is mainly known for glucose in adipocytes [43, 72]. Our studies extended this concept to skeletal muscle proteolysis [84] and lactate production [83].

\subsection{Thyroid hormones}

The responsiveness of whole body proteolysis (measured by the endogenous leucine appearance rate in a postabsorptive state) was investigated in healthy volunteers [75] and hypothyroidic patients before and after long-term thyroid hormone therapy. The protocol therefore allows one to analyse the effect of both hypothyroidism in patients and hyperthyroidism in healthy volunteers. The effect of insulin was measured under the hyperinsulinemic-euglycemic euaminoacidemic clamp by the slope of a dose response curve of insulin sensitivity of leucine appearance rate (in $\mu \mathrm{mol}$ leucine $\mathrm{kg}^{-1} \cdot \mathrm{min}^{-1} / \mathrm{nmol}$ insulin/L). The ability of insulin to inhibit proteolysis linearly increased as a function of plasma thyroid hormones $(0.13 \pm 0.03$ in hypothyroidic patients, $0.23 \pm 0.02$ in euthyroidic patients, $1.01 \pm 0.8$ in normal subjects and $1.59 \pm$ 0.11 in hyperthyroidic subjects; the corresponding T3 levels, in $\mathrm{pmol} / \mathrm{L}$, were $1.4 \pm$ $0.15,3.7 \pm 0.9,7.7 \pm 0.5$ and $18.1 \pm 1.1$ ) [76] (Rochon et al., unpublished results).

\subsection{Lactation}

Milk synthesis, especially in high-yielding ruminants, needs large amounts of substrates. To meet their requirements, animals 
improve food intake. Unfortunately, amino acid supplies from the digestive tract are clearly not sufficient to support milk protein synthesis. By an adaptative mechanism, there is a decrease in the use of amino acids in the extramammary tissues (which makes the amino acids available to the mammary gland). A loss of skeletal muscle protein has been reported, which may be due to the contribution of both an increase in protein degradation and a decrease in protein synthesis [14]. By using very similar investigations to those performed in humans (see above), we demonstrated that the insulininhibited proteolysis was improved during early lactation. This adaptation originated from an amino acid deficit during that period because it was eliminated by hyperaminoacidemia [79]. Other factors or hormones associated with the beginning of lactation presumably also play a role. The phenomenon is consistent with the improvement of the ability of insulin to depress glucose production, which we demonstrated previously [22]. Both adaptative processes would lead to saving of body proteins, amino acids, and gluconeogenic substrates.

\section{CONCLUSIONS}

Insulin plays an important role in the regulation of skeletal muscle protein turnover in vivo. It promotes protein deposition both by the inhibition of proteolysis and stimulation of protein synthesis. The inhibition of whole body proteolysis is very well recognised. Recent studies clearly demonstrate that insulin acts in skeletal muscle on the ATP-ubiquitin-proteasome pathway by decreasing ubiquitin expression. In contrast, the ability of insulin infusion to stimulate muscle protein synthesis is only evident in young growing animals in a postabsorptive state. Acute postprandial insulin suppression by diazoxide should now provide a better understanding on the direct relationship between insulin and protein synthesis in vivo. The cascade of events from the insulin receptors to the targets (eIF-2B, 4E-BP1, some specific genes, etc.) also needs to be elucidated.

To prevent or limit muscle atrophy in humans, a better knowledge is needed concerning the mechanism of muscle wasting. Muscle proteins are lost when protein synthesis is low compared to proteolysis. These

Table I. Changes in insulin action during catabolic states.

\begin{tabular}{lccc}
\hline $\begin{array}{l}\text { Catabolic factor } \\
\text { (with references) }\end{array}$ & \multicolumn{2}{c}{ Change in insulin action } & $\begin{array}{c}\text { Consequence for } \\
\text { muscle wasting }\end{array}$ \\
\cline { 2 - 4 } & On protein synthesis & On proteolysis & \\
\hline Streptozotocin diabetes [39] & decreased & decreased & facilitated \\
Glucocorticold excess [20] & decreased & decreased & facilitated \\
$\begin{array}{l}\text { Hypothyroidism } \\
\text { (Rochon and Grizard, unpublished) }\end{array}$ & N.D. & decreased & facilitated \\
$\begin{array}{l}\text { Cytokine-induced sepsis [84] } \\
\text { Hyperthyroidism [77] }\end{array}$ & unchanged & decreased & facilitated \\
Early lactation in goats [79] & N.D. & improved & counteracted \\
\hline
\end{tabular}

N.D., not determined. 
pathways are highly regulated by catabolic factors which either decrease protein synthesis or stimulate proteolysis. Both pathways could also be simultaneously targeted. Glucocorticoids, thyroid hormones, cytokines and insulin suppression typically represent catabolic factors.

The present review clearly demonstrates that the catabolic states induced consistent changes in insulin action on muscle protein turnover (table I). Moreover there was a decrease in insulin action, which facilitates the effect of catabolic factors. This mechanism, no doubt participates in muscle wasting during ageing since old subjects are more often exposed to stress, injuries and neuroendocrine dysfunctions (e.g. diabetes and decreases in plasma thyroid hormones). In contrast, insulin may prevent excessive muscle wasting during hyperthyroidism and early lactation in ruminants. Indeed, the antiproteolytic effect of insulin was improved in these situations. These adaptative changes in insulin action need to be better understood, based on the knowledge of insulin signalling pathways and mediators. The physiological importance of these changes in the control of skeletal muscle protein metabolism remains to be established.

\section{REFERENCES}

[1] Attaix D., Taillandier D., Temparis S., Larbaud D., Aurousseau E., Combaret L., Voisin L., Regulation of ATP-ubiquitin-dependent proteolysis in muscle wasting, Reprod. Nutr. Dev. 34 (1994) 583-597.

[2] Attaix D., Aurousseau E., Combaret E., Kee A., Larbaud D., Rallière C., Souweine B., Taillandier D., Tilignac T., Ubiquitin-proteasomedependent proteolysis in skeletal muscle, Reprod. Nutr. Dev. 38 (1998) 153-165.

[3] Attaix D., Taillandier D., The critical role of the ubiquitin-proteasome pathway in muscle wasting in comparison to lysosomal and $\mathrm{Ca}^{2+}$-dependent systems. Intracellular protein degradation, in: Rivett A.J. (Ed.), Adv. Mol. Cell. Biol. 27 (1998) 235-266.

[4] Backer J.M., White M.F., Phosphatidylinositol 3'-kinase and insulin action, in: Draznin B., Le Roith D. (Eds.), Molecular Biology of Diabetes, Humana Press Inc., 1994. pp. 115-144.
[5] Bailey J.L., Price S.R., England B.K., Jurkovitz C., Wang X., Ding X., Mitch W.E., Signals regulating accelerated muscle protein catabolism in uremia, Min. Electrol. Metab. 23 (1997) 198-200.

[6] Baillie A.G.S., Garlick P.J., Responses of protein synthesis in different skeletal muscles to fasting and insulin in rats, Am. J. Physiol. 260 (1991) E891-E896.

[7] Baillie A.G.S., Garlick P.J., Attenuated responses of muscle protein synthesis to fasting and insulin in adult female rats, Am. J. Physiol. 262 (1992) E1-E5.

[8] Bennet W.M., Connacher A.A., Scrimgeour C.M., Jung R.T., Rennie M.J., Euglycemic hyperinsulinemia augments amino acid uptake by human leg tissues during hyperaminoacidemia, Am. J. Physiol. 259 (1990) E185-E194.

[9] Biolo G., Fleming R.Y.D., Wolfe R.R., Physiologic hyperinsulinemia stimulates protein synthesis and enhances transport of selected amino acids in human skeletal muscle, J. Clin. Invest. 95 (1995) 811-819.

[10] Block N.E., Buse M.G., Effects of hypercotisolemia and diabetes on skeletal muscle insulin receptor function in vitro and in vivo, Am. J. Physiol. 256 (1989) E39-E48.

[11] Bogoyevitch M.A., Sugden P.H., The role of protein kinases in adaptational growth of the heart, Int. J. Biochem. Cell Biol. 28 (1996) 1-12.

[12] Burant C.F., Treutelaar M.K., Buse M.G., Diabetes-induced functional and structural changes in insulin receptors from rat skeletal muscle, J. Clin. Invest. 77 (1986) 260-270.

[13] Castellino P., Luzi L., Simonson D.C., Haymond M., De Fronzo R.A., Effect of insulin and plasma amino acid concentrations on leucine metabolism in man. Role of substrate availability on estimates of whole body protein synthesis, J. Clin. Invest. 80 (1987) 1784-1793.

[14] Champredon C., Debras E., Patureau Mirand P., Arnal M., Methionine flux and tissue protein synthesis in lactating and dry goats, J. Nutr. 120 (1990) 1006-1015.

[15] Cheatham B., Kahn C.R., Insulin action and the insulin signaling network, Endocrine Rev, 16 (1995) 117-142.

[16] Ciechanover A., The ubiquitin-proteasome proteolytic pathway, Cell 79 (1994) 13-21.

[17] Dardevet D., Sornet C., Attaix D., Baracos V.E., Grizard J., Insulin-like growth factor-1 and insulin resistance in skeletal muscles of adult and old rats, Endocrinology 134 (1994) 1475-1484.

[18] Dardevet D., Sornet C., Taillandier D., Savary I., Attaix D., Grizard J., Sensitivity and protein turnover response to glucocorticoids are different in skeletal muscle from adult and old rats. Lack of regulation of the ubiquitin-proteasome proteolytic pathway in aging, J. Clin. Invest. 96 (1995) 2113-2119. 
[19] Dardevet D., Sornet C., Vary T., Grizard J., Phosphatidylinositol 3-kinase and p70 S6 kinase participate in the regulation of protein turnover in skeletal muscle by insulin-like growth factor $\mathrm{I}$, Endocrinology 137 (1996) 4087-4094.

[20] Dardevet D., Sornet C., Savary I., Debras E., Patureau Mirand P., Grizard J., Glucocorticoid effects on insulin- and IGF-I regulated muscle protein metabolism during aging, J. Endocrinol. 156 (1998) 83-89.

[21] Davis T.A., Burrin D.G., Fiorotto M.L., Reeds P.J., Jahoor F., Roles of insulin and amino acids in the regulation of protein synthesis in the neonate, J. Nutr. 128 (1998) S347-S350.

[22] Debras E., Grizard J., Aina E., Tesseraud S., Champredon C., Arnal M., Insulin sensitivity and responsiveness during lactation and dry period in goats, Am. J. Physiol. 256 (1989) E295-E302.

[23] Denne S.C., Liechty E.A., Liu Y.M., Brechtel G., Baron A.D., Proteolysis in skeletal muscle and whole body in response to euglycemic hyperinsulinemia in normal adults, Am. J. Physiol. 261 (1991) E809-E814.

[24] Duckworth W.C., Bennett R.G., Hamel F.G., A direct inhibitory effect of insulin on a cytosolic proteolytic complex containing insulindegrading enzyme and multicatalytic proteinase J. Biol. Chem. 269 (1994) 24575-24580.

[25] Fagan J.M., Waxman L., Goldberg A.L., Skeletal muscle and liver contain a soluble $\mathrm{ATP}^{+}$ ubiquitin-dependent proteolytic system, Biochem. J. 243 (1987) 335-343.

[26] Flaim K.E., Copenhaver M.B., Jefferson L.S., Effects of diabetes on protein synthesis in fastand slow-twitch rat skeletal muscle, Am. J. Physiol. 239 (1980) E88-E95.

[27] Flakoll P.J., Kulaylat M., Frexes-Steed M., Hourani H., Brown L.L., Hill J.O., Abumrad N.N., Amino acids augment insulin's suppression of whole body proteolysis, Am. J. Physiol. 257 (1989) E839-E847.

[28] Fluckey J.D., Vary T.C., Jefferson L.S., Evans W.J., Farrell P.A., Insulin stimulation of protein synthesis in rat skeletal muscle following resistance exercise is maintained with advancing age, J. Geront. Series A - Biol. Sci. Med. Sci. 51 (1996) B323-B330.

[29] Fryburg D.A., Jahn L.A., Hill S.A., Oliveras D.M., Barrett E.J., Insulin and insulin-like growth factor-I enhance human skeletal muscle protein anabolism during hyperaminoacidemia by different mechanisms, J. Clin. Invest. 96 (1995) 1722-1729.

[30] Garlick P.J., Fern M., Preedy V.R., The effect of insulin infusion and food intake on muscle protein synthesis in postabsorptive rats, Biochem. J. 210 (1983) 669-676.

[31] Garlick P.J., Grant I., Amino acid infusion increases the sensitivity of muscle protein synthesis in vivo to insulin, Effect of branched- chain amino acids, Biochem. J. 254 (1988) 579-584.

[32] Gelfand R.A., Barrett E.J., Effect of physiologic hyperinsulinemia on skeletal muscle protein synthesis and breakdown in man, J. Clin. Invest. 80 (1987) $1-6$.

[33] Giordano M., Castellino P., DeFronzo R.A., Differential responsiveness of protein synthesis and degradation to amino acid availability in humans, Diabetes 45 (1996) 393-399.

[34] Giorgino F., Chen J.H., Smith R.J., Changes in tyrosine phosphorylation of insulin receptors and a 170000 molecular weight nonreceptor protein invivo in skeletal muscle of streptozotocin. Induced diabetic rats - effects of insulin and glucose, Endocrinology 130 (1992) 1433-1444.

[35] Giorgino F., Almahfouz A., Goodyear L.J. Smith R.J., Glucocorticoid regulation of insulin receptor and substrate IRS-1 tyrosine phosphorylation in rat skeletal muscle in vivo, J. Clin. Invest. 91 (1993) 2020-2030.

[36] Goldberg A.L., Rock K.L., Proteolysis, proteasomes and antigen presentation, Nature 357 (1992) 375-379.

[37] Grizard J., Dardevet D., Papet I., Mosoni L., Patureau Mirand P., Attaix D., Tauveron I., Bonin D., Arnal M., Nutrient regulation of skeletal muscle protein metabolism in animals. The involvement of hormones substrates, Nutr. Res. Rev. 81 (1995) 67-91

[38] Grizard J., Dardevet D., Savary I., Mosoni L., Meynial-Denis D., Amal M.A., Patureau Mirand P., Implication de l'insuline et des glucocorticoïdes dans la fonte protéique musculaire chez le rat au cours du vieillissement, L'année gérontologique, Nutrition et Vieillissement (suppl.) (1998) in press.

[39] Grzelkowska K., Dardevet D., Balage M. Grizard J., Involvement of rapamycin-sensitive pathway in the insulin regulation of muscle protein synthesis in streptozotocin-diabetic rats, J. Endocrinol. (1998) in press.

[40] Haghighat A., Mader S., Pariso A., Sonenberg N., Repression of cap dependent translation by $4^{E}$-binding protein, I: competition with p220 binding to eukaryotic intiation factor- $4{ }^{\mathrm{E}}, \mathrm{EMBO}$. J. 14 (1995) 5701-5709.

[41] Heslin M.J., Newman E., Wolf R.F., Pisters P.W.T., Brennan M.F., Effect of hyperinsulinemia on whole body and skeletal muscle leucine carbon kinetics in humans, Am. J. Physiol. 262 (1992) E911-E918

[42] Hillier T.A., Fryburg D.A., Jahn L.A., Barrett E.J. Extreme hyperinsulinemia masks insulin's effect to stimulate protein synthesis in the human forearm, Am. J. Physiol. E (1998) in press.

[43] Hotamisligil G.S., Peraldi P., Budavari A., Ellis R., White M.F., Spiegelman B.M., IRS-1-mediated inhibition of insulin receptor tyrosine kinase activity in TNF-alpha- and obesity-induced insulin resistance, Science 271 (1996) 665-668. 
[44] Johnson P., Calpains (intracellular calcium-activated cysteine proteinases): structure-activity relationships and involvement in normal and abnormal cellular metabolism, Int. J. Biochem. 22 (1990) 811-822.

[45] Karinch A.M., Kimball S.R., Vary T.C., Jefferson L.S., Regulation of eukaryotic initiation factor-2B activity in muscle of diabetic rats, Am. J. Physiol. 264 (1993) E101-E108.

[46] Kettelhut I.C., Wing S.S., Goldberg A.L., Endocrine regulation of protein breakdown in skeletal muscle, Diabetes/Metab. Rev. 4 (1988) 751-772.

[47] Kimball S.R., Vary T.C., Jefferson L.S., Regulation of protein synthesis by insulin, Ann. Rev. Physiol. 56 (1994) 321-348.

[48] Kimball S.R., Jefferson L.S., Fadden P., Haystead T.A.J., Lawrence J.C., Insulin and diabetes cause reciprocal changes in the association of eIF-4E and PHAS-I in rat skeletal muscle, Am. J. Physiol.-Cell Physiol. 270 (1996) C705-C709.

[49] Kimball S.R., Mellor H., Flowers K.M., Jefferson L.S., Role of translation initiation factor eIF-2B in the regulation of protein synthesis in mammalian cells, in: Cohn W.E., Moldave K. (Eds.), Progress in Nucleic Acid Research and Molecular Biology, Vol. 54 (Series: Progress in Nucleic Acid Research and Molecular Biology 54), Academic Press Inc., 1996, pp. 165-196.

[50] Larbaud D., Debras E., Taillandier D., Samuels S., Temparis S., Champredon C., Grizard J., Attaix D., Euglycemic hyperinsulinemia and hyperaminoacidemia decreases skeletal muscle ubiquitin mRNA in goats, Am. J. Physiol. 271 (1996) E505-E512.

[51] Lobley G.E., Nutritional and hormonal control of peripheral tissue metaolism in farm species, Livestock Prod. Sci. (1998) in press.

[52] Louard R.J., Fryburg D.A., Gelfand R.A., Barrett E.J., Insulin sensitivity of protein and glucose metabolism in human forearm skeletal muscle, J. Clin. Invest. 90 (1992) 2348-2354.

[53] McNulty P.H., Young L.H., Barrett E.J., Response of rat heart and skeletal muscle protein in vivo to insulin and amino acid infusion, Am. J. Physiol. 264 (1993) E958-E965.

[54] McNurlan M.A., Essen P., Thorell A., Calder A.G., Anderson S.E., Ljungqvist O., Sandgren A., Grant I., Tjader I., Ballmer P.E., Wernerman J., Garlick P.J., Response of protein synthesis in human skeletal muscle to insulin: an investigation with L-[H2(5)]phenylalanine, Am. J. Physiol. 267 (1994) E102-E108.

[55] Medina R., Wing S.S., Goldberg A.L., Increase in levels of polyubiquitin and proteasome mRNA in skeletal muscle during starvation and denervation atrophy, Biochem. J. 307 (1995) 631-637.
[56] Millward D.J., Rivers J.P.W., The needs for indispensable amino acids: the concept of the anabolic drive, Diabetes/Metab. Rev. 5 (1989) 191-211.

[57] Möller-Loswick A.C., Zachrisson H., Hyltander A., Körner U., Matthews D.E., Lundholm K., Insulin selectively attenuates breakdown of nonmyofibrillar proteins in peripheral tissues of normal men, Am. J. Physiol. 266 (1994) E645-E652.

[58] Mosoni L., Houlier M.L., Patureau Mirand P., Bayle G., Grizard J., Effect of amino acids alone or with insulin on muscle and liver protein synthesis in adult and old rats, Am. J. Physiol. 264 (1993) E614-E620.

[59] Myers M.G., White M.F., Insulin signal transduction and the IRS proteins, Ann. Rev. Pharmacol. Toxicol. 36 (1996) 615-658.

[60] Odedra B.R., Dalal S.S., Millward D.J., Muscle protein synthesis in the streptozotocin-diabetic rat. A possible role for corticosterone in the insensitivity to insulin infusion in vivo, Biochem. J. 202 (1982) 363-368.

[61] Pain V.M., Albertse E.C., Garlick P.J., Protein metabolism in skeletal muscle, diaphragm and heart of diabetic rats, Am. J. Physiol. 245 (1983) E604-E610.

[62] Pain V.M., Initiation of protein synthesis in eukaryotic cells, Eur. J. Biochem. 236 (1996) 747-771.

[63] Pepato M.T., Migliorini R.H., Goldberg A.L., Kettelhut I.C., Role of different proteolytic pathways in degradation of muscle protein from streptozotocin-diabetic rats, Am. J. Physiol. Endocrinol. Metab. 271 (1996) E340-E347.

[64] Peraldi P., Spiegelman B.M., Studies of the mechanism of inhibition of insulin signaling by tumor necrosis factor-alpha, J. Endocrinol. 155 (1997) 219-220.

[65] Rechsteiner M., Natural substrates of the ubiquitin proteolytic pathway, Cell 66 (1991) 615-618.

[66] Redpath N.T., Proud C.G., Molecular mechanisms in the control of translation by hormones and growth factors, Biochem. Biophys. Acta Mol. Cell Res. 1220 (1994) 147-162.

[67] Russell-Jones D.L., Umpleby M., Protein anabolic action of insulin, growth hormone and insulin-like growth factor I, Eur. J. Endocrinol. 135 (1996) 631-642.

[68] Saad M.J.A., Araki E., Miralpeix M., Rothenberg P.L., White M.F., Kahn C.R., Regulation of insulin receptor substrate-1 in liver and muscle of animal models of insulin resistance, J. Clin. Invest. 90 (1992) 1839-1849.

[69] Saad M.J.A., Folli F., Kahn J.A., Kahn C.R., Modulation of insulin receptor, insulin receptor substrate-1, and phosphatidylinositol 3-kinase in liver and muscle of dexamethasone-treated rats, J. Clin. Invest. 92 (1993) 2065-2072. 
[70] Savary I., Debras E., Dardevet D., Sornet C., Capitan P., Prugnaud J., Patureau Mirand P., Grizard J., Effect of glucocorticoid excess on skeletal muscle and heart protein synthesis in adult and old rats, Br. J. Nutr. 79 (1998) 297-304.

[71] Savary I., Dardevet D., Debras E., Sornet C., Patureau Mirand P., Grizard J., Protein synthesis in adult and old rats, in: French-Polish symposium on nutrition and animal physiology, Paris, 1998.

[72] Sinaud S., Balage M., Bayle G., Dardevet D., Vary T.C., Kimball S.R., Jefferson L.S., Grizard J., Diazoxide-induced insulin deficiency greatly reduced muscle protein synthesis in rats. Involvement of eIF-4E, Am. J. Physiol. E (1999) in press.

[73] Stephens J.M., Lee J., Pilch P.F., Tumor necrosis factor-alpha-induced insulin resistance in 3T3-L1 adipocytes is accompanied by a loss of insulin receptor substrate- 1 and GLUT4 expression without a loss of insulin receptor mediated signal transduction, J. Biol. Chem. 272 (1997) 971-976.

[74] Sun X.J., Wang L.M., Zhang Y.T., Yenush L., Myers M.G., Glasheen E., Lane W.S., Pierce J.H., White M.F., Role of IRS-2 in insulin and cytokine signalling, Nature 377 (1995) 173-177.

[75] Tauveron I., Grizard J., Thieblot Ph., Bonin D., Adaptation métabolique en hyperthyroidie, implication de l'insuline, Diab. Metab. 18 (1992) 131-136.

[76] Tauveron I., Larbaud D., Champredon C., Debras E., Tesseraud S., Bayle G., Bonnet Y., Thieblot P., Grizard J., Effect of hyperinsulinemia and hyperaminoacidemia on muscle and liver protein synthesis in lactating goats, Am. J. Physiol. 267 (1994) E877-E885.

[77] Tauveron I., Charrier S., Champredon C., Bonnet Y., Berry C., Bayle G., Prugnaud J., Obled C., Grizard J., Thiéblot P., Response of leucine metabolism to hyperinsulinemia under amino acid replacement in experimental hyperthyroidism, Am. J. Physiol. 269.(1995) E499-E507.

[78] Tessari P., Inchiostro S., Biolo G., Trevisan R., Fantin G., Marescotti M.C., Iori E., Tiengo A., Crepaldi G., Differential effects of hyperinsulinemia and hyperaminoacidemia on leucinecarbon metabolism in vivo, J. Clin. Invest. 79 (1987) 1062-1069.
[79] Tesseraud S., Grizard J., Debras E., Papet I., Bonnet Y., Bayle G., Champredon C., Leucine metabolism in lactating and dry goats: effect of insulin and substrate availability, Am. J. Physiol. 265 (1993) E402-E413.

[80] Thompson M.G., Palmer R.M., Signalling pathways regulating protein turnover in skeletal muscle, Cell. Sign. 10 (1998) 1-11.

[81] Tiao G., Fagan J.M., Samuels N., James J.H., Hudson K., Lieberman M., Fischer J.E., Hasselgren P.O., Sepsis stimulates nonlysosomal, energy-dependent proteolysis and increases ubiquitin mRNA levels in rat skeletal muscle, J. Clin. Invest. 94 (1994) 2255-2264.

[82] Vary T.C., Jurasinski C.V., Karinch A.M., Kimball S.R., Regulation of eukaryotic initiation factor-2 expression during sepsis, Am. J. Physiol. 266 (1994) E193-E201.

[83] Vary T.C., Dardevet D., Obled C., Pouyet C., Breuillé D., Grizard J., Modulation of skeletal muscle lactate metabolism following bacteremia by insulin or insulin-like growth factor-I: effects of pentoxifylline, Shock 7 (1997) 432-438.

[84] Vary T.C., Dardevet D., Grizard J., Voisin L., Buffière C., Denis P., Breuillé D., Obled C., Differential regulation of skeletal muscle protein turnover by insulin and IGF- 1 after bacteremia, Am. J. Physiol. 275 (1998) E584-E593.

[85] Voisin L., Breuillé D., Combaret L., Pouyet C., Taillandier D., Aurousseau E., Obled C., Attaix D., Muscle wasting in a rat model of long lasting sepsis results from the activation of lysosomal, $\mathrm{Ca}^{2+}$-activated and ubiquitin-proteasome proteolytic pathways, J. Clin. Invest. 97 (1996) 1610-1617.

[86] Wing S.S., Banville D., 14-kDa ubiquitin-conjugating enzyme: structure of the rat gene and regulation upon fasting and by insulin, Am. J. Physiol. 267 (1994) E39-E48.

[87] Wu J., Dent P., Sturgill T.W., Map kinase pathways and insulin action, in: Draznin B., Le Roith D. (Eds.), Molecular Biology of Diabetes, Humana Press Inc., 1994, pp. 157-177.

[88] Yenush L., White M.F., The IRS-signalling system during insulin and cytokine action, BioAssays 19 (1997) 491-500.

[89] Yoshizawa F., Kimball S.R., Jefferson L.S., Modulation of translation initiation in rat skeletal muscle and liver in response to food intake, Biochem. Biophys. Res. Commun. 240 (1997) 825-831. 